\title{
Disaster resilient vernacular housing technology in Nepal
}

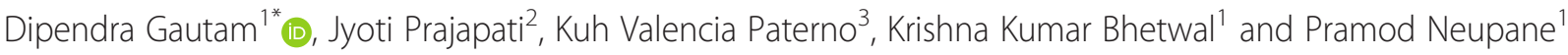

\begin{abstract}
Background: Disasters like earthquakes and flood cause enormous loss of lives and property in Nepal frequently. However, during such events particular types of houses are found to be more resilient than common types of housing stocks. This paper outlines the disaster resilient vernacular housing technologies in two of the physiographic regions of Nepal. The vernacular houses are analyzed in terms of their performance and shortcomings during earthquake and flood disasters and found to be technologically resilient in many aspects of impending disasters in Nepal distributed within the physiographic regions. Using the comparative case study approach, field visits and non-structured interviews with local people, the resilient features in terms of construction technology of vernacular houses are identified in this study and the preliminary findings are highlighted as observed during the field visits without numerical modeling and analysis. The seismic performance of Rajbanshi, Gurung and Magar houses in Nepal during 1934, 1988 and 2015 earthquakes is presented in order to justify the performance of these particular housing stocks.

Results: The vernacular construction technology in Terai is found to be technologically resilient in terms of floods and earthquakes, and earthquake resistant technologies are identified in the dwellings of the western mid-hill of Nepal. The traditional Rajbanshi houses in eastern Nepal are found to be resilient in terms of earthquake and flood disasters and the Gurung and Magar houses in western mid hills are found to be resilient in terms of earthquake disaster. The statistical distribution of housing stocks is presented and survival scenario is discussed with regard to specific building features. Apart from this, the field reconnaissance after Gorkha earthquake in western Nepal shows better performance of buildings with identified features in comparison to common housing stocks in neighborhoods.

Conclusions: As there is no instant possibility of enforcing building codes and guidelines for earthquake and floods resistant construction technologies and replacing the structures by modern reinforced concrete construction across the country and even people throughout Nepal are not able to afford the modern aspects of disaster resilient constructions; identified resilient features of houses are instrumental in assuring safety, serviceability, cultural comfort, patrimony and resilient livelihoods in rural and suburban setups of Nepal. The vernacular constructions also incorporate the cost effectiveness with proper use of local materials and cultural reflections in housing units. Global paradigms have shown significant performance during past disaster events, so replication of such technology with due incorporation of strengthening measures may be pivotal for country like Nepal.
\end{abstract}

Keywords: Disaster, Vernacular housing technology, Resilience, Earthquake, Flood, Nepal

\footnotetext{
* Correspondence: strdyn@yahoo.com

${ }^{1}$ Structural and Earthquake Engineering Research Institute, Kathmandu, Nepal

Full list of author information is available at the end of the article
}

\section{实 Springer}

(c) 2016 Gautam et al. Open Access This article is distributed under the terms of the Creative Commons Attribution 4.0 International License (http://creativecommons.org/licenses/by/4.0/), which permits unrestricted use, distribution, and reproduction in any medium, provided you give appropriate credit to the original author(s) and the source, provide a link to the Creative Commons license, and indicate if changes were made. 


\section{Background}

Vernacular housing constructions are unique and local technologies of constructions in local areas engrossed by the local people, resources and knowledge. Throughout the world, vernacular housing constructions are significantly occurring and their rational and resilient features are nowadays more recognized in terms of sustainability (Oktay and Pontikis 2008; Jordan and O'Neill 2010; Aziz and Shawket 2011; Afshar et al. 2012; Wided et al. 2012; Jiboye 2014; Tutuko and Shen 2014; Langenbach 2015; Lima et al. 2015; Varum et al. 2015). Non-engineered vernacular dwellings abundantly exist worldwide where majority share of houses is occurred in rural and suburban settlements (Saleh 2001; Yamin et al. 2004; Ferrigni et al 2005; Mundo-Hernandez et al. 2013; Widera and Despang 2013; GhaffarianHoseini et al. 2014; Donovan and Gkartzios 2014) and a countable fraction in urban areas. Nepal consists of $83 \%$ rural population and about $90 \%$ of total houses in Nepal are non-engineered constructions (CBS 2012), this depicts the wider presence of vernacular non-engineered dwellings.

There is an inherent linkage between the disasters and housing, though such correlation is more amplified in developing countries where housing is considered amongst the most valuable assets for the people (Chang et al. 2010; Ahmed 2011). Global paradigms in various disasters and environmental conditions have reflected an accountable performance of vernacular dwellings in terms of survival and low damage intensity during past disaster events (e.g., Boen 2001; Bouchair and Dupagne 2003; Gulkan and Langebach 2004; Bouillot 2008; Dixit et al. 2008; SDMC 2008; Amirrol 2010; Zhai and Previteli 2010; Audefory 2011; Cheng et al. 2011; Nguyen et al. 2011; Anh 2012; Bodach et al. 2014; Gautam 2014; Malalgoda et al. 2014; Yung et al. 2014; Gautam and Rodrigues 2015). As the effective disaster coping mechanisms start right from the local building culture (CRAterre 2013, Moles et al. 2014), the resilient features of vernacular housing should be carefully judged along with the impending disasters. Vernacular constructions are practiced for many centuries and it is obvious that the many parts of the world would be more sticked on this technology for centuries as well due to economic and technological constraints in terms of switching the construction practice towards reinforced concrete. Carrying on vernacular technology will be undergirded by the extensive use of local resources and dynamic characteristics of technology itself in terms of adaptation to available resources and continuous hit a trial by the local practitioners. The evolution based on gradual modification through hit and trial has led the vernacular technology to be dynamic and compliant with the contemporary socio-economic setup.

Nepal is characterized by frequent disaster events like; floods and earthquakes where substantial loss of lives, infrastructures and properties is occurred every year. In the period of 1900-2005, as many as 1674 flood events were reported in Terai region of Nepal causing 2856193 casualties (Aryal 2012). The great Bihar-Nepal earthquake of magnitude 8.1 claimed lives of 8519 people along with more than 200000 houses damaged across the country (Rana 1935). Another notable earthquake of magnitude 6.5 in 1988 claimed lives of 721 people with 66382 buildings damaged (Dixit et al. 2013). In addition to these earthquakes, the magnitude 6.9, 2011 SikkimNepal border earthquake caused extensive damage on rural houses of eastern Nepal. The severe impact of 2015 Gorkha earthquake (magnitude 7.8) is reflected in terms of 8790 casualties, 22300 injuries and 498852 houses completely or partially collapsed and other 256697 houses partly damaged (NPC 2015). In this regard, flood and earthquakes are amongst the most fatal disasters claiming enormous life and property loss in Nepal, so it is imperative to study the local response and resilience in local level. Most of the rural and suburban settlements in Nepal have established their own tradition in building construction apart from the recent modern reinforced concrete (RC) construction, which dominates only in urban areas and newer settlements. Some municipalities in Nepal have enforced Mandatory rule of Thumbs (MRT) as suggested in Nepal Building Code (NBC) for the construction of RC buildings, though majority of population is concentrated in rural areas where building codes are nevertheless enforced. Without prior guidelines on disaster resilient construction technology; locally developed and approved technologies have been obtaining legitimacy in suburbs and rural settlements and reflected in almost of the dwellings as local architecture irrespective of ethnic origin and cultural descent. People are not advised in terms of disaster resilient construction with regard to frequent disasters concentrated to particular area, so local craftsmanship has been contributing in developing resilient technologies through continuous trial and error and many on occasions through experiences from past disaster events (e.g., Rana 1935; Gautam 2014).

In the hilly region of Nepal, earthquake impacts are more disastrous due to topographical/ridge effects, foundation type and lack of structural integrity and the Terai region is particularly susceptible to floods and flashfloods triggered by annual torrential precipitation and also earthquake impacts are widely distributed. Earthquake risk is distributed in all physiographic regions in Nepal as suggested by the frequent seismic events in the entire Hind-Kush-Himalayan region.

Past earthquake events from 1255, 1260, 1408, 1681, 1767, 1810, 1823, 1833, 1834, 1837, 1869, 1917, 1934, 1936, 1954, 1965, 1966, 1980, 1988,2011 and 2015 have depicted severe damage scenarios in Nepal in terms of 
structural collapse, life and property damage (Dixit et al. 2013; NPC 2015). Beside several detrimental cases of structural collapses in other types of houses, timber framed houses are the resilient ones in every earthquake event in Nepal (Rana 1935; JSCE 1989; Gautam et al. 2015) and also timber frames are justified as seismic resistant features globally (e.g., Poletti et al. 2015). Similarly, the flood events of 1993 and 2008 have severely affected the Terai region of Nepal in terms of life and property loss (UNDP 2008). After the $1988 \mathrm{M}_{\mathrm{W}} 6.5$ Udaypur, earthquake resistant construction and design of structures got more attention, as the consequence of this earthquake, Nepal Building Code was formulated in 1994 by the Ministry of Housing and Physical Planning. This building code incorporates only the earthquake disaster to consider during building construction for buildings demanding state-of-the art design, engineered buildings, pre-engineered design for non-engineered buildings through mandatory rule of thumb and rural and owner-built houses (NBC 1994). Several efforts regarding earthquake resistant constructions are being implemented after the formulation of building codes. Mason trainings, seismic vulnerability assessment and retrofitting of school buildings and government offices, building code implementation programs are some of the visible outputs mirrored after the formulation of Nepal Building Code (Dixit 2014). After the promulgation of Natural Calamities Relief Act in 1982 for the first time in South Asian region, Nepal stepped up into responding the natural disasters, however till date, it is in the same primitive form without any revisions and compliance, though the specifics and frequency of disaster events, structural and social vulnerabilities are largely increased with mushrooming population. The ongoing discussion on disaster management act in Nepal is expected to address many impending disasters and associated preparedness activities in Nepal. Majority of discussions and guidelines till date are developed for urban setups of Nepal as these guidelines and policies do not necessarily incorporate countryside. Similarly, National Plan of Action for Disaster Management (1994), Kathmandu Valley Earthquake Risk Management Project (1997-2005), Study on Earthquake Disaster Mitigation for Kathmandu Valley (2000-2002) by JICA, Shelter Policy (2006), National Strategy for Disaster Risk Management (2009), Nepal Risk Reduction Consortium (2009) have put some efforts in disaster risk reduction through consortium of government, non-government offices, aid agencies and development partners, yet more focus is visible on urban centers and suburbs. Mandatory rule of thumb (MRT) for building constructions are more pronounced and implemented in suburbs and some villages, though MRT incorporates only modern construction practices. Strengthening of vernacular construction technology is incorporated in Nepal Building Codes (NBC 203 and NBC 204), however such technologies and capacity building trainings in local level are rarely propagated in remote villages. Due to high dependence of Nepal Building Code with Indian Standard Code of practice, only the MRT section of Nepal Building Code is practiced, however in case of engineered construction practices, almost all designs and analysis are done considering the Indian Standard Code of Practice IS 456:2000 and IS 1893:2002. This paradigm should be accounted for ameliorating the Nepal Building Code by incorporating Nepalese aspects of construction materials, technology transfer and improvement, disaster scenarios and workmanships and economic status.

In average, some 70 flood events occur in every monsoon in Nepal (Gautam 2015a) so earthquakes and floods are more highlighted disasters in terms of loss of life and impact upon physical infrastructures and properties. Regarding flood resistant construction, Nepal Building Code and other guidelines are still silent in addressing the impacts and countermeasures. Risk sensitive land use planning, land use planning and zoning are not effectively researched and implemented in rural setups of Nepal. Overall flood fighting mechanisms like construction of embankments, levees, and plantation are promoted in Nepal.

Due to growing interests and practices of RC constructions, local appropriate technologies developed from local resources are not effectively researched and promoted in Nepal. As some of the key features of vernacular constructions are being forgotten in recent decades, present paper reviews local housing technology from Terai and Hilly regions of Nepal and outlines local construction technologies in relation to their performance, efficacy and disaster resilience. Engrossing the performance of houses in the aftermath of 2015 Gorkha earthquake is pivotal in assuring sustainable and resilient livelihoods in any physiographic region. Retrofitting and strengthening of vernacular dwellings and the concept of rural and suburban reconstruction in Nepal have nowadays more pronounced in the aftermath of Gorkha earthquake. Local strengthening solutions like buttresses, corner posts, corner ties and wall bracings could be viable solutions for feebly damaged houses so as to assure the life and property of local people in rural Nepal. Prior to formulation of such frameworks it is imperative to identify the resilient features of vernacular constructions in terms of construction technology and their performance paradigm during past events. Such features may be adopted during rural/ sub-urban reconstruction, strengthening and retrofitting as well. In this context, this paper highlights the local practices of constructions in technological aspect which have performed better during past disaster events. Taking into consideration of floods and earthquakes, housing technologies are analyzed as per the construction aspect and technological soundness. 


\section{Study area}

The physiographic composition in Nepal (Fig. 1) reflects the smallest fraction of land in Terai (about $17 \%$ ) followed by the Hills (about $18 \%$ ) and the Mountains (about $65 \%$ ). At the meantime, Terai has gotten the largest share of population (50.27\%) followed by Hills (43.00\%) and Mountainous region (6.73\%) (CBS 2012). From east to west and north to south there is widespread variation in terms of social, cultural and geographical aspects in Nepal. Likewise these variations, housing constructions are also different and more localized due to social composition and cultural diversities. The localization of housing construction technology varies as per the materials, craftsmanship, inherent threats and challenges like animal attack to environmental adversities. Two districts of Nepal Jhapa (Terai) and Kaski (Hill) are chosen for analyzing the local housing technology with regard to disaster resilient features. Both of these districts are easily accessible by road transport and also ideal place in terms of indigenous settlements. Jhapa has the significant fraction of wooden pillared houses and is also densely populated by the indigenous Rajbanshis, Dhimals and Satars (ethnic communities found only in eastern Nepal) who have contributed better in developing the vernacular architecture for centuries. Similarly, in Kaski the significant fraction of houses is occupied by the mud bonded bricks or stones related with the construction of rounded houses. These two districts have unique architecture and performance of these particular types of houses has been justified in three strong earthquakes of 1934, 1988 and 2015. The Rajbanshi architecture in the entire Terai is unique one, as most of mid and western Terai belts have no trend of constructions with platform. Similarly, the rounded houses are typically found in western mid-hills only. Moreover, densely populated Gurung (an ethnic group in mid hills of Nepal) settlements are also prevalent in Kaski and unique architectural composition has been practiced and refined for centuries. Thus Kaski and Jhapa are chosen as study site so as to obtain representative housing technologies in terms of indigenous inputs and associated resilient features learned and incorporated from

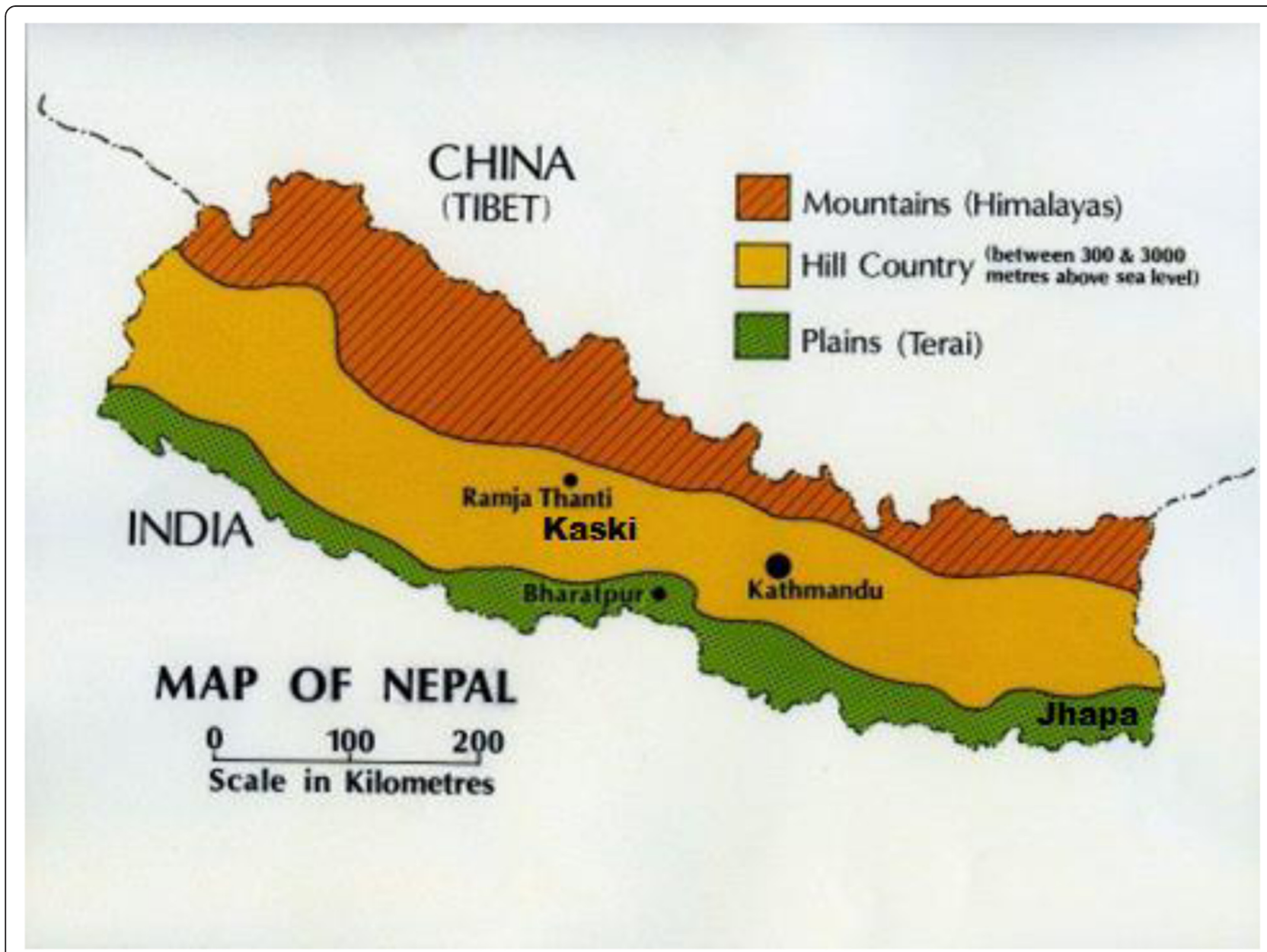

Fig. 1 Physiographic map of Nepal (Modified from: http://www.johntyman.com/nepal/01.html) 
past disaster events. Entire Nepal is under grave threat of seismic events as Nepal lies in the subduction zone of Indian plate beneath the Eurasian plate so the local housing technologies are studied with respect to earthquake resilient features and associated construction technologies. Due to widespread plain land and low topographical relief, flood is normally occurred in Jhapa almost every monsoon and due to topographical conditions and gregarious settlements mid-hills may suffer from severe loss during earthquakes so Kaski district is chosen as representative study area.

\section{Methods}

Field visits in two of the case study districts (Jhapa and Kaski) were performed and the representative houses were studied. Analysis in terms of the composition, materials, technology, relevance and sustainability was performed as desk study after collecting data on field. Phenomenological studies in terms of performance during disasters, non-structured and informal interviews were performed during the field visits. A comparative case study approach (Yin 2003) was adopted due to purely explanatory nature of this research. The resilient features of the houses were disseminated as many as possible during field visits. Non-structured interviews with masons with regard to the construction processes and materials used were performed and interaction with local old aged people (as young people and women seldom participate in construction activities), community leaders were also done so as to understand the adaptation, endorsement and construction framework of vernacular houses. In addition to this, informal interactions with educated people and community leaders, phenomenological observations and desk studies were performed. As complete understanding of the processes and technologies needs long terms exposure and involvement in communities, so this study is only a preliminary highlight regarding the good practices and justified evidences from the past. Detailed numerical analysis and modeling will be disseminated in future contribution for understanding the performance behavior of houses.

While formulating the disaster resilient vernacular dwellings in each physiographic region of Nepal; 15 representative vernacular houses from Jhapa and 15 rounded houses (Ghumauro dhi) from Kaski were taken as case study dwellings as such constructions are dominant in the specific physiographic regions. The studied houses from indigenous communities are chosen in study- 15 Rajbanshi houses from Maheshpur village development committee of Jhapa and 15 Gurung houses from Sarankot village of Kaski districts are studied. While studying those houses owners were interviewed in terms of age of buildings, how they used such technologies, what materials were used and where they obtained such materials, why they chose particular form of houses and what benefits they are observing from such houses. Identified disasters vis-à-vis prevalent construction technology has been disseminated in this study. Sample houses are justified with the disaster resilient technological features and the shortcomings are identified for introducing remedies in some extent for future constructions and strengthening of particular types of houses. This paper only incorporates the technological aspects of vernacular housing; however sustainability should be compliant with the cultural, social, economic and environmental aspects.

\section{Result and discussions}

\section{Vernacular housing construction technology and} performance of vernacular houses during disasters

RC construction in Nepal started only after 1980. However, modern RC construction system till date is concentrated only in urban areas and some suburbs. Only 9.94\% buildings are RC constructions, moreover cement bonded constructions are $17.57 \%$, wooden pillars $24.9 \%$, mud-bonded bricks $44.21 \%$ (Fig. 2) hence the dominance of non-engineered vernacular constructions throughout Nepal is well reflected and obvious. Meanwhile, as per the wall systems of houses in Nepal, majority fraction of walls is constituted by mud bonded bricks or stones (41.38\%). Other wall systems like cement bonded bricks or stones (28.74 \%), bamboo $(20.23 \%)$ and wooden walls $(5.31 \%)$ are in significant fraction (Fig. 3). As most of the houses are concentrated in rural neighborhoods of Nepal suggested by $83 \%$ population concentration in suburbs and rural setups (CBS 2012), majority fraction of wall system is incorporated by mud bonded bricks or stones, bamboo and wooden planks for walls. Cement bonded walls are common in urban and suburban areas. The roofing system in houses is dominated by galvanized sheet after 1980 and yet the locally available slate, tile or straw is being extensively used in rural Nepal (Fig. 4). After galvanized sheets, tile slate (26.68\%), RCC (22.48 \%) and thatched straw (19.0.3 \%) are common types of roofing systems in Nepal. Notably, before the use of galvanized sheet most of the houses used to be covered by thatched/straw roofs. The reinforced concrete cement roofing system is dominant only in urban areas, district headquarters, suburbs and commercial centers. Particular types of houses were identified to be undamaged or less damaged during 1934 Bihar Nepal, 1988 Udaypur and 2015 Gorkha earthquakes in comparison to other types of houses. Likewise during interviews, the local older people from Jhapa remarked that the houses with wooden pillars were survived or less damaged during 1988 earthquake in Nepal and also those rounded 




Fig. 2 Distribution of housing systems as per types of structures in Nepal

houses were among the good performers during the same event in Kaski. This is consistent with the description presented by Rana (1935), report compiled by JSCE (1989) and study performed by various teams after the 2015 Gorkha earthquake (e.g., Gautam et al. 2015). During the great Bihar-Nepal earthquake of 1934, Jhapa district didn't suffer from any structural damage (Rana 1935) though the epicenter was near, this clearly depicts the resilience of wooden pillared structures during earthquakes. Also, during many flood events, those houses with wooden pillars were resilient than other types of houses with their superstructure started right from the ground surface in the vicinity as per the local people. The 1988 eastern Nepal earthquake was devastating event for eastern Nepal and also Kaski was severely affected during this event, however there was clear distinction between particular types of houses with other common types of houses, as per the local people. It is found that, the Rajbanshi houses and the rounded Gurung houses are resilient constructions as depicted by their performance





during several past earthquakes. The features of houses are analyzed in terms of elemental contribution to holistic housing performance to minimize the impact of disaster events on case by case basis.

\section{Vernacular housing technology in Terai: floods and earthquake resilience}

In the Terai region, inundation is common due to plain terrain having low altitudes. Housing construction in this region is guided by creating a platform up to certain height (usually from $1 \mathrm{~m}$ to $3 \mathrm{~m}$ ) which is unconstructed open and arrangement of the living environment is started from the first storey above the unconstructed platform (Fig. 5). Due to water logging problems, locally available and dampness resistant heartwood of Shorea robusta was found to be used as wooden pillar running up to the roof level. Construction in such buildings is limited to first storey only, however the gable part of houses are isolated by creating a wooden slab or slab constructed using bamboo. Such low height and weight houses constructed with timber elements have sound performance during earthquakes due to high ductility and low weight of overall construction. Although, majority of houses in Jhapa are found to be constructed of mud bonded bricks or stones (91.99\%), before 1990 very few houses were of mud bonded bricks. Beside this, the vernacular wooden pillar houses $(4.21 \%)$ and cement bonded bricks/stones (3.04 \%) are other dominant housing types in Jhapa (Fig. 6). Due to availability of timber for construction from the forests of "Sal" Shorea robusta in the vicinity, people used to focus on such housing construction and wooden pillared houses were dominant even during the 1988 earthquake. Such housing construction was relatively economic practice due to widespread use of local materials in terms of timber and bamboo. During interaction all of the 15 houses were found to be constructed in less than $\$ 500$ due to instant availability of resources during their 


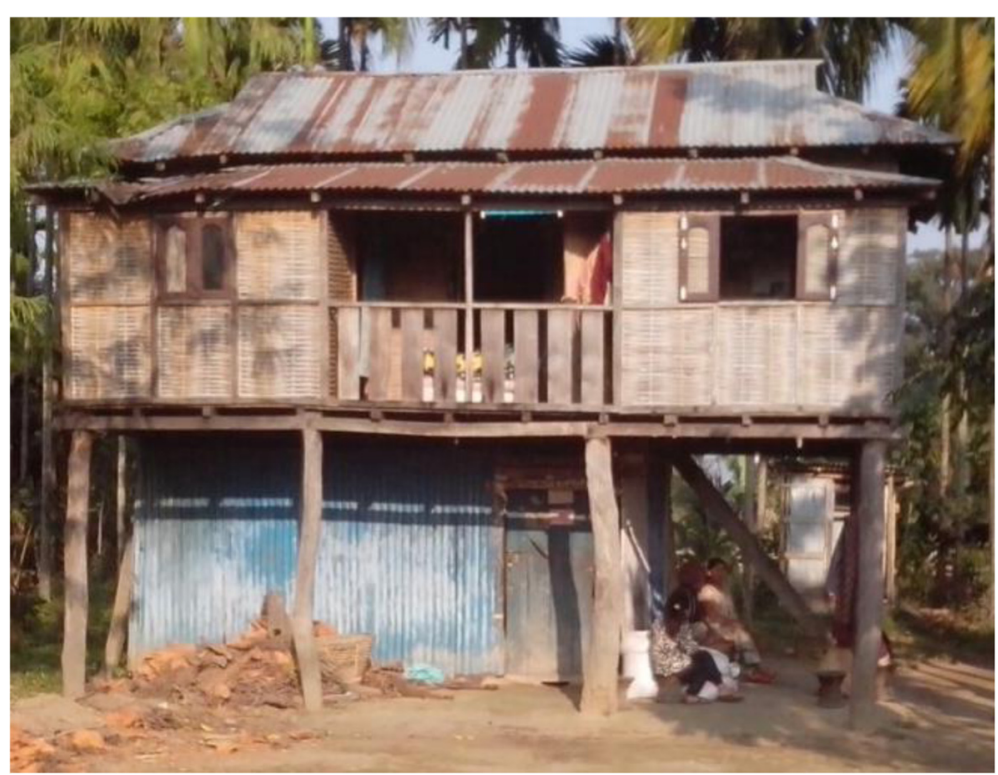

Fig. 5 Common vernacular Rajbanshi house in Jhapa (Terai)

construction time some 20 to 40 years back. The technology was locally developed and adopted so local craftsmanship was effectively used in order to delineate the appropriate technology of housing construction in Jhapa. During interviews with community leaders, it is found that, after the 1988 Udaypur earthquake many of the people from other ethnic origins also adopted the similar construction technology so as to reconstruct their houses. This is evidently verified by the significant occurrence of similar types of constructions in many areas of this district. In such vernacular constructions, the wall system is dominated by the mud bonded bricks or stones $(82.32 \%)$ and next to this, wood or planks $(9.53 \%)$ are dominant over the vernacular constructions followed by cement bonded bricks/stones (7.46 \%)
(Fig. 7). As in Fig. 5, walls of majority of the studied houses were constructed from bamboo ikra (net constructed from bamboo sticks tied together). Wall system and partitioning is provided with the ikra having relatively low weight and easy circulation of air as a countermeasure against relatively higher temperature than any other physiographic regions of Nepal. Thermal comfort in such houses is easily achieved through a wooden slab below roof and provision of sufficient openings.

These dwellings have mud (48.55\%), galvanized iron sheets $(30.94 \%)$ and wooden planks $(16.51 \%)$ as dominant roofing materials (Fig. 8). Mud is adopted from the traditional roofing system for passive solar cooling and heating in comparison to other roofing materials so as to avoid the burning heat during daytime and prevent the attack of cold waves during winter.

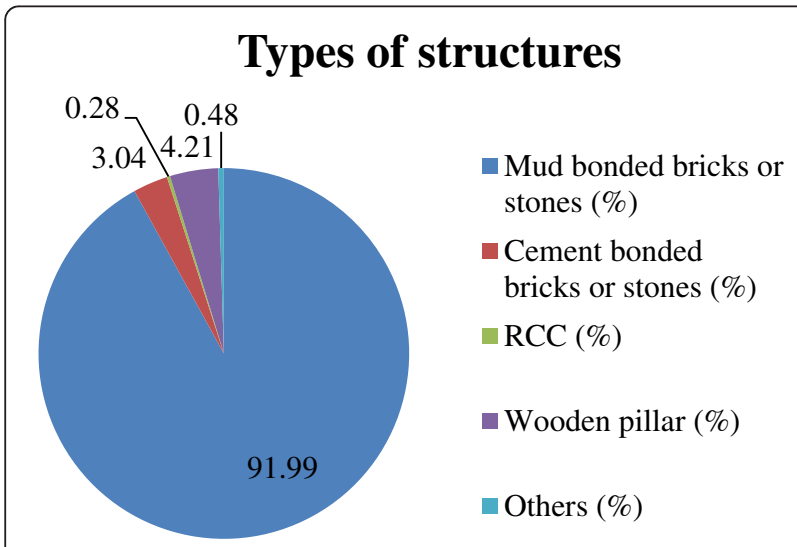

Fig. 6 Distribution of houses as per types of structure in Jhapa

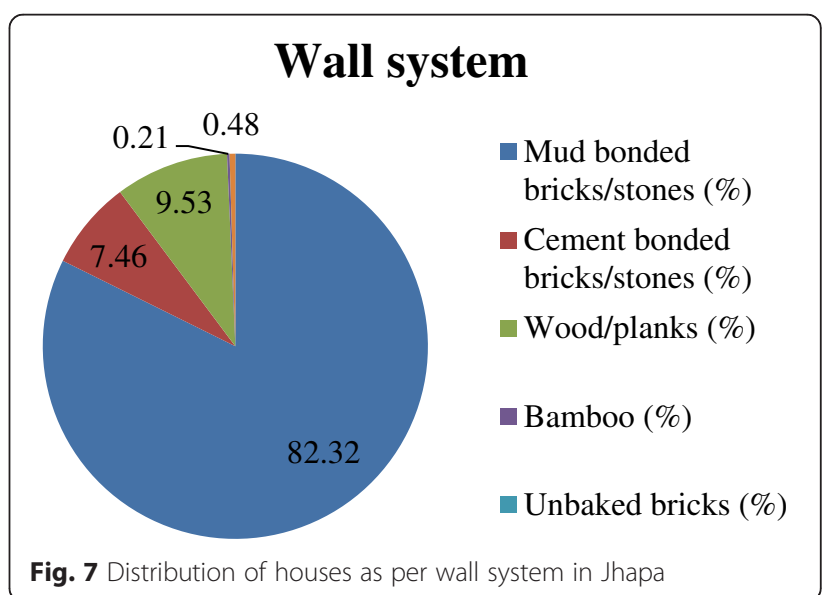




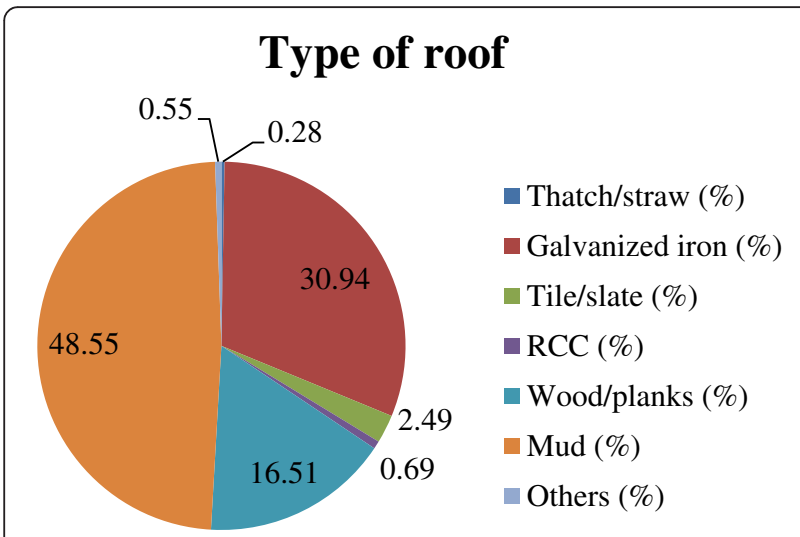

Fig. 8 Distribution of houses as per types of roof in Jhapa

About $80 \%$ of precipitation occurs in Nepal from June through September, during this season, the entire Terai region observes inundation problems. While accounting such inundation and staying safe from the attacks from epidemics and snake attack and thermal comfort through proper air circulation additionally; local people usually prefer such construction since early settlement stages. The local older respondents remarked that during past time there used to be severe cases of floods so that ground storied houses were found to be problematic in order to reside and also there used to be frequent attacks of snakes and other predatory species as well, evidently it was found true for some of the ethnic communities who have cultural restriction to construct more than one storied house or constructing a platform before starting first storey. In order to overcome such calamities, present technologies were developed some 40 years back as per the respondents' argument. This is an instrumental depiction of local people so as to enhance the resilience in local level with local materials and state-of- art. The construction technology is not sophisticated and doesn't require specialized manpower; however a simple rectangular construction technology with four to six wooden pillars running from foundation to roof is prevalent in case study area. Such simple and symmetric construction is also efficient in terms of balancing the torsional effects during earthquakes. Such appropriate technology is guided by earthquake resistant features, flood and damping resilience and also to prevent snake attacks. Due to economic constraints new houses were also observed to be adopting the similar construction technology in study area.

\section{Vernacular dwellings in hills: earthquake resilience}

In the mid-hills of Nepal basically the Gurung and Magar settlements (indigenous groups in western midhills of Nepal) are dominant. In this region people have developed a unique tradition of housing construction. These are called as Ghumauro dhi locally. The rounded structures (Fig. 9) constructed from stone masonry with countable fraction of timber elements are excellent examples in earthquake resilient features (SDMC 2008; Gautam 2015b). While selecting the timbers, it has been noticed during field visit, heartwood ("Agrakh" as per local people) from local trees was found to be used for major components like timber posts and rafters. Ghumauro dhi is a symmetrical circular construction, usually one to two storied where timber elements are introduced in the form of openings, slabs and struts at various levels.

The overall distribution of houses in Kaski shows the dominance of mud bonded bricks or stones (91.99\%) followed by wooden pillar constructions (4.21\%) and cement/mud bonded bricks or stones (3.04 \%) (Fig. 10). The studied houses fall under the category of mud bonded stone houses. As per the local people, majority

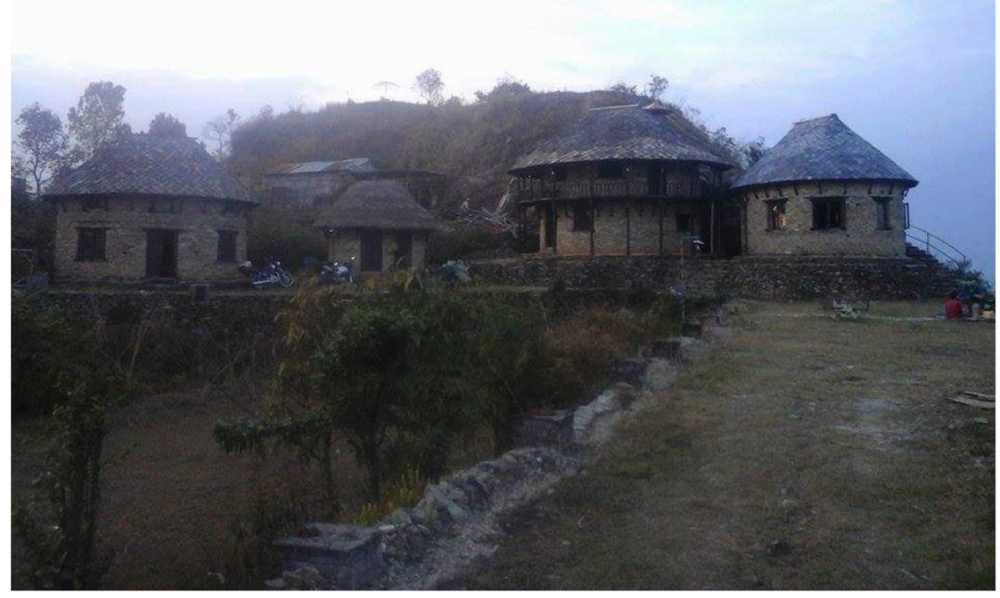

Fig. 9 Common vernacular dwelling in western mid-hill (Kaski) of Nepal 


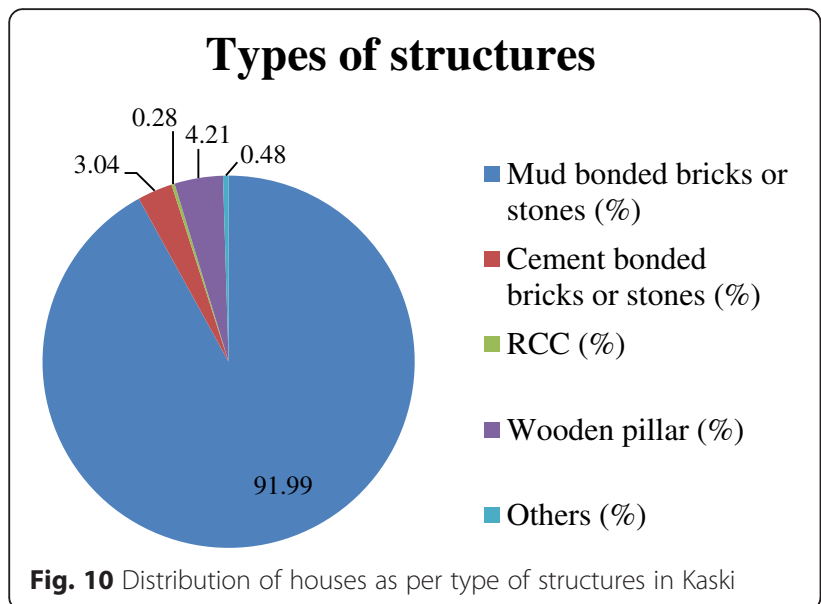

of the indigenous settlements in Kaski follow the similar pattern of housing units with exception to some modern constructions. These houses have dominant mud bonded bricks or stone walls $(82.32 \%)$ as façade, and wooden planks as facade $(9.53 \%)$ and cement bonded brick façade $(7.46 \%)$ are also significantly practiced in Kaski district (Fig. 11). However, the vernacular construction is ever-dominating the other construction technologies and typology of structures in terms of wall systems. Availability of local resources like stones, timber, straw and mud-mortar has effectively contributed in economic constructions, development of local economy as well as investment and employment opportunities in local level consequently supporting the livelihoods in local level. Such houses in the case study site were found to be of around 50-150 years of age and the construction cost was ranging from $\$ 100$ to $\$ 300$ at that time.

Roofing in such construction is usually provided with the locally available mud (48.54\%), galvanized iron (30.94 \%), and tile/slate (2.49 \%) (Fig. 12). In the study area, all 15 houses were with seasoned stones properly tied with iron wires assuring integral framework of

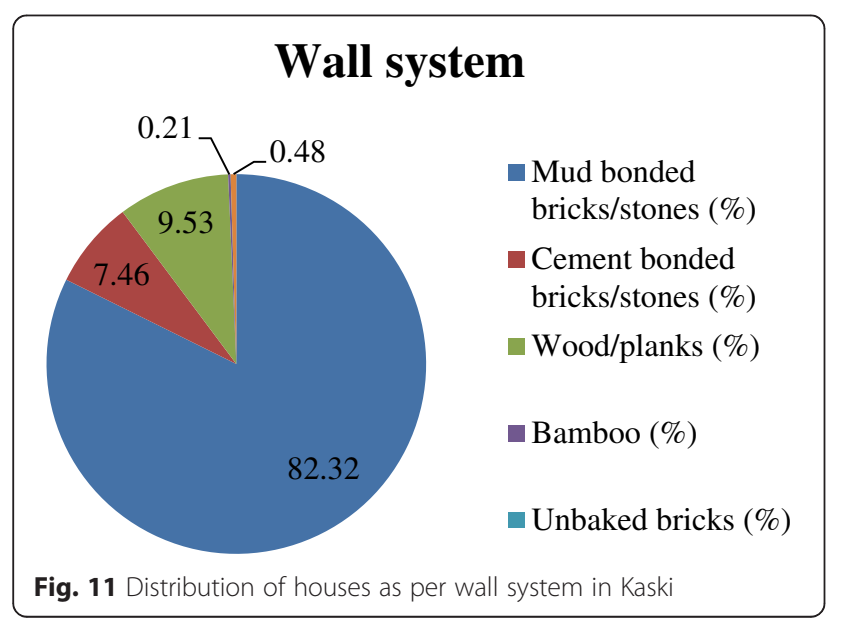



Fig. 12 Distribution of houses as per type of roof in Kaski

homogenous roofing. The stone units were ultimately found to be connected with purlins so as to stick better and prevent from falling. The subsequent load reduction while constructing upper parts of buildings was identified as one of the most unique feature leading to earthquake resistant construction practice, which is also endorsed by modern building codes. Wooden pegs were found to be commonly deployed for tying the various materials and rafter of the roof in such houses. The openings were found to be smaller so that majority of the load bearing walls is covered by wall units contributing in better structural integrity. In such constructions, pancake destruction and soft storey problems are never observed due to presence of wooden bands in lintel level or sill level, so sometimes such features perform better than deficient RC structures (e.g., Langenbach 2010). Locally, people provide sill band ("Nas") which has significant contribution in avoiding the out of plane collapse.

During past events like the 1934 Bihar-Nepal and the 1988 Udaypur earthquakes and recently during 2015 Gorkha earthquake, damage was particularly less in such constructions due to symmetry and low rise construction (Rana 1935; JSCE 1989; Gautam et al. 2015). The mainstreamed load transfer mechanism for the cantilevered portion of such houses is found to be facilitated by the struts, as these struts have directed the outward load into the load bearing walls. The rounded structures have a coinciding center of gravity and center of rigidity avoiding possible torsional phenomenon during earthquakes. Foundation leveling is found to be ensured through construction of stone plinths for strapped foundation and hence the sloped terrains was even consisting the leveled foundations.

\section{Shortcomings of vernacular constructions}

In local construction practice of hilly region, the binding material used is mud mortar which is the prime cause leading to lack of structural integrity and poor bonding of housing units. There can be seen cracks on walls due 
to uneven settlements after construction. Such cracks can serve as stress concentration points and the effect could be detrimental during earthquakes. If timber structures are constructed, good resilience against earthquake effects could be ensured. In Terai region, people usually construct their houses beside or within the arable land as entire Terai region has relatively plain relief throughout and most of the population is dependent in agricultural practices with regular irrigation in cultivated lands. This practice has created problem in rapid decay of wooden columns for the sapwood pillars so proper selection of timber is instrumental in assuring the performance of houses in long run. In this regard, people may get better site in relatively higher topographical relief in case of availability or use drains around the houses so as to avoid inundation. Such techniques may be beneficial for people to adopt and enhance the life span of houses. In the other hand, during the field visit it is observed that heartwood timber used for timber framing was remarkably less affected by the groundwater so proper selection of timber frames is crucial in vernacular houses of Terai. As the strengthening and retrofitting methods of vernacular houses have been seldom discussed in Nepal except few cases (e.g., Bothara and Brzev 2012), such structures need immediate attention due to the fact that majority of structures are vernacular non-engineered ones and are being used for very long time. Attention towards construction technologies and capacity building of local masons haven't been implemented so people are obliged to follow traditional construction technologies only. Juxtaposition of modern findings and verified vernacular elements within such constructions could be pivotal in ensuring disaster resilience in rural Nepal.

\section{Future insight}

As majority fractions of Nepalese buildings are guided by the vernacular construction aspects and technologies, their performance and technological resilience largely determine the loss of life and property in case of disaster events. Vernacular housing technology is the most costeffective practice which utilizes the local workmanship and materials and also endorses the cultural dimensions of indigenous and local people as well. In this regard, appropriate technologies are justified in terms of economic efficacy and cultural endorsement. Beyond this, with regard to comfort and lessons from the past events, vernacular constructions are the products of continuous trial and errors, incorporating many features that are resilient aginst particular type of disasters. While incorporating countermeasures against several risks and their impacts, vernacular technologies are developed and found across the world. The performance of Dhajji-dewari, Nias, Himis, LambanTuha, Pombalino, Newari Chhen, Casa Baracada, Bhungas, Batak, Lombok, Tasikmalaya, among others during past events has proven the efficacy of vernacular houses (Boen 2001; Decanini et al. 2004; Gulkan and Langenbach 2004; Bothara et al. 2007; Winarno et al. 2008; Amirrol 2010; Gautam 2014, Ortega et al. 2015; Gautam and Rodrigues 2015). In this regard cultural aspects and local resource led economic and appropriate constructions are incorporated in most of the indigenous settlements. Though there are some shortcomings of vernacular houses, however such shortcomings could be easily overcome by implementing some countermeasures as suggested and incorporated by the Bureau of Indian Standard (BIS 2012). In order to assure life and property, Nepal urgently needs some frameworks for strengthening and retrofitting techniques for the vernacular houses thus the economic constructions could be carried on. Beside this, the cultural dimensions are nevertheless addressed by modern RC and steel construction technologies, so in order to assure culturally sound and disaster resilient neighbourhoods; some guidelines are to be formulated incorporating the prevalent disasters in local scales. The cost of construction is usually high for modern $\mathrm{RC}$ buildings so it would be rational to promote the vernacular constructions both in order to preserve cultural aspects as well as for economic construction. There is severe destruction in rural houses during 2015 Gorkha earthquake (Fig. 13) so reconstruction should be guided by the earthquake resistant features in local level, however there is negligible damage in timber framed (Fig. 14) and rounded houses (Fig. 15) in western Nepal so these lessons should be thoroughly incorporated. Beside these, proper identification and verification of disaster resilient technologies are urgently needed. Meanwhile, some strengthening measures are also needed for the survived houses which have observed minor damages. As the vernacular constructions would continue for ages, it would be imperative to incorporate the identified features employing some additional resilient characteristics and elements in new constructions. For this capacity building is necessary and should reach upto the local communities. In order to construct/reconstruct culturally appropriate and to assure patrimony, promotion and enhancement of local technology could be effectively utilized in Nepal. In building codes, the blended framework of verified resilient features along with recently developed technical aspects should be incorporated to preserve cultural dimensions of local people so that resilient and culturally sound constructions would be promoted more. As there are many paradigms in the world hinged with such blending and their performance is justified as well, like in Dhajji construction (UN Habitat and National Disaster Management Authority, Pakistan 2009) Nepal could pragmatically endorse and reinforce sustainable construction/ reconstruction mechanism using insights from performance of vernacular houses. 


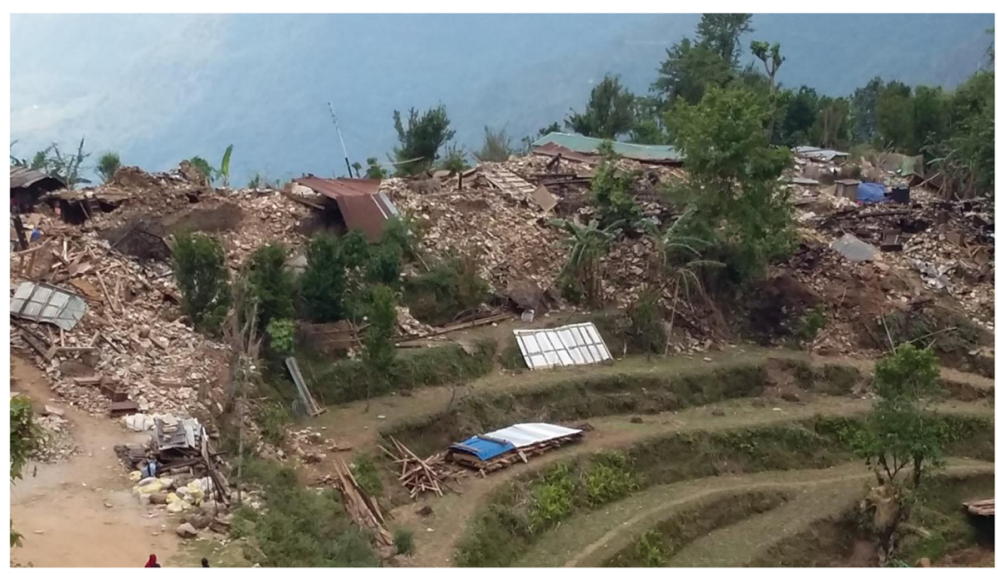

Fig. 13 Completely collapsed dry stone masonry houses in entire neighborhood of western Nepal after 2015 Gorkha earthquake

\section{Conclusion}

Honed by continuous trial and error and juxtaposing the experiences of past events, vernacular technology has appreciably contributed in terms of resilience and sustainable construction in suburban and rural Nepal. Use of local materials, manpower and technology has brought a unique trend of construction in Nepal in terms of vernacular technology. Each physiographic unit has own tradition of vernacular dwellings. In Terai, people seek some dimensions of construction with regard to flood resilience primarily, so they have been constructing houses with raised platform. Such houses with raised platform are usually of one to two storied and having less weight. Thermal comfort is also ensured through use of locally casted partitioning materials. Relatively durable timber like Shorea robusta ("Agrakh") is used for such construction. The housing technology also incorporates many aspects of earthquake resistant features like symmetrical construction, high ductility, proper binding of housing units, among others. Such features were developed from continuous trial and error efforts after several past disaster events. In the case of hills, people have developed a tradition of one to two storied constructions with proper use of symmetrical rounded configuration. Earthquake resilient technology is proven through implementation of elements like struts, timber bands, low storey height and smaller openings, mainstreamed cantilevered load on structural walls, subsequent load reduction in upper stories, proper connection of roof with other structural system, among others. Leveled foundation is also a characteristic practice in hills even if the terrain is not leveled. Nepal, being an underdeveloped country, has weak framework of disaster resilient construction and execution in rural setups and suburbs. Even in the urban areas, the NBC is surpassed by the



Fig. 14 A house with timber lacing and corner posts in the same stretch of western Nepal which survived during 1988 and 2015 earthquakes 


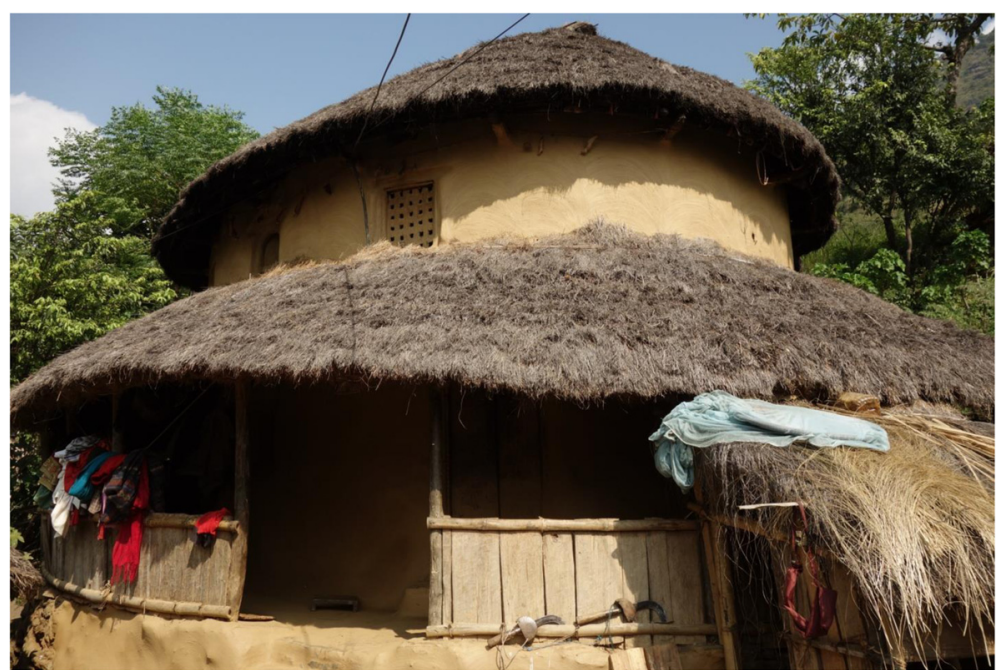

Fig. 15 A 150 years old rounded house in western Nepal survived during 1934, 1988 and 2015 earthquakes without any damage

Indian Standard codes of practice due to high dependence of NBC into IS code. Thus, it is obvious that, there is lack of proper mechanism to govern the local construction technology. People have developed themselves some unique features of construction which are proven to be earthquake resilient against prevalent disasters of small to medium scales. There are still several things lagging in vernacular construction technology, beside this the remarkable features from vernacular practice might be instrumental in governing and assuring disaster resilient construction technology economically and locally in greater extent. People, if devised with regard to the remarkable features of such construction and provided with some additional low cost features like lateral supports (buttresses), improved local binding materials, configuration, site selection, among others; resilience could be remarkably enhanced. Such construction framework would be surely cost-effective due to use of local materials and also culturally sound through reflection of local customs replicated in households. Many of the global paradigms have shown remarkable performance of vernacular houses during past disaster events, so replication, modification, blending with modern concepts, incorporating in building codes and construction guidelines could be pivotal in assuring disaster resilience in suburbs and rural setups. As most of the people are not able to pay for modern sophisticated engineered constructions, they will continue to construct similar types of structures hence their performance evaluation and strengthening frameworks are needed for assuring safety, patrimony and resilience.

\section{Competing interests}

The authors declare that they have no competing interests.

\section{Authors' contributions}

DG and JP collected the data and went for field study. KVP, KKB and PN suggested on methodology and did data analyses. DG, JP and KVP prepared first draft and KKB and PN modified and enriched the text with research relevance. KKB and PN also enhanced the research framework and engrossed the analysis. All five authors read and approved the final manuscript.

\section{Acknowledgement}

Authors express sincere gratitude to Mr. Randolph Langenbach (conservationtech, USA), Mr. Rabindra Prajapati (civil engineer), Prof. Ranjan Kumar Dahal (Tribhuvan University), Prof. GS Bhardwaj (India) and Mr. Kshitij Thebe for providing us valuable feedbacks and information. Special thanks go to the respondents and interviewee during field visits. The constructive comments from two referees are sincerely acknowledged.

\section{Author details}

${ }^{1}$ Structural and Earthquake Engineering Research Institute, Kathmandu, Nepal. ${ }^{2}$ Department of Hydrology and Meteorology, Kathmandu, Government of Nepal. ${ }^{3}$ Partido State University, Goa, Philippines.

Received: 8 June 2015 Accepted: 4 February 2016

Published online: 20 February 2016

\section{References}

Afshar, A., W. Alaghbari, E. Salleh, and A. Salim. 2012. Affordable housing design with application of vernacular architecture in Kish Island, Iran. International Journal of Housing Markets and Analysis 5(1): 89-107. doi:10.1108/17538271211206680.

Ahmed, I. 2011. An overview of post-disaster permanent housing reconstruction in developing countries. International Journal of Disaster Resilience in the Built Environment 2(2011): 148-164.

Amirrol H. 2010. Structural genius of indigenous Nias house architecture. http:// www.scribd.com/doc/31105246/Structural-Genius-of-Indigenous-Nias-HouseArchitecture. Accessed 23 July 2014

Anh, T.T. 2012. Likelihood of innovative construction techniques to build disaster resilience for vernacular housing in the highlands of central Vietnam. Journal of Civil Engineering and Architecture 6(10): 1392-1398.

Aryal, K.R. 2012. The history of disaster incidents and impacts in Nepal 1900-2005. International Journal of Disaster Risk Science 3(3): 147-154.

Audefory, J.F. 2011. Haiti: post earthquake lessons learned from traditional construction. Environment and Urbanization, International Institute for Environment and Development (IIED) 23(2): Xx-xx. doi:10.1177/0956247811418736.

Aziz, T.A., and I.M. Shawket. 2011. New strategy of upgrading slum areas in developing countries using vernacular trends to achieve a sustainable housing development. Energy Procedia 6(2011): 228-235. doi:10.1016/j. egypro.2011.05.026. 
BIS (Bureau of Indian Standards). 2012. Draft Building Code of India, Part 11 Approach to Sustainability, p. 11.

Bodach, S., W. Lang, and J. Hamhaber. 2014. Climate responsive building design strategies of vernacular housing in Nepal. Energy and Buildings 81(2014): 227-242.

Boen, T. 2001. Earthquake resistant design of non-engineered buildings in Indonesia. Kamakura: Paper presented at the EQTAP Workshop.

Bothara, J., and S. Brzev. 2012. A tutorial: Improving the seismic performance of stone masonry buildings. Oakland: Earthquake Engineering Research Institute.

Bothara, J.K., J.B. Mander, R.P. Dhakal, R.K. Khare, and M.M. Maniyar. 2007. Seismic performance and financial risk of masonry house. ISET Journal of Earthquake Technology 44(3-4): 421-444

Bouchair, A., and A. Dupagne. 2003. Building traditions of Mzab facing the challenges of re-shaping of its built form and society. Building and Environment 38(2003): 1345-1364.

Bouillot, J. 2008. Climatic design of vernacular housing in different provinces of China. Journal of Environmental Management 87(2008): 287-299.

CBS (Central Bureau of Statistics). 2012. Nepal Population and Housing Census, National Report. Central Bureau of Statistics Nepal, Vol. 01 NPHC 2011.

Chang, Y., S. Wilkinson, R. Potangaroa, and E. Seville. 2010. Resourcing challenges for post-disaster housing reconstruction: a comparative analysis. Building Research \& Information 38(3): 247-264.

Cheng, H., J. Liu, D. Wang, W. Zhou, R. Hu, and D. Liu. 2011. Eco-friendly vernacular rural housing in western China: a case study of a reconstruction project after 2008 Sichuan earthquake. Applied Mechanics and Materials 99100(2011): 638-643

CRAterre. 2013. Natural hazards, disasters and local development, Building cultures and sustainable development (edition) available at: craterre.org/ diffusion:ouvrages.../14803_natural_hazards_disasters.pdf

Decanini, L., A.D. Sortis, A. Goretti, R. Langenbach, F. Mollaioli, and A. Rasulo. 2004. Performance of masonry buildings during the 2002 Molise, Italy, Earthquake. Earthquake Spectra 20(S1): S191-S220.

Dixit AM. 2014. Earthquake disaster risk management efforts in Nepal. Paper presented at the International Symposium Geohazards: Science, Engineering and Management

Dixit AM, Guragain R, Shrestha SN, Gupta M, Sharma A. 2008. Understanding traditional wisdom of earthquake-resistant construction in the Himalayas. Paper presented at The $14^{\text {th }}$ World Conference on Earthquake Engineering, Beijing, China.

Dixit, A.M., R. Yatabe, R.K. Dahal, and N.P. Bhandary. 2013. Initiatives for earthquake disaster risk management in the Kathmandu valley. Natural Hazards 69: 631-654.

Donovan, K., and M. Gkartzios. 2014. Architecture and rural planning: claiming the vernacular. Land Use Policy 41(2014): 334-343.

Ferrigni, F., B. Helly, A. Mauro, L. Mendes Victor, P. Pierotti, A. Rideaud, and P. Teves Costa. 2005. Ancient Buildings and Earthquakes: Reducing the Vulnerability of Historical Built- Up Environment by Recovering the Local Seismic Culture: Principles, Methods, Potentialities. Bari: Edipuglia.

Gautam, D. 2014. The building features acquired from the indigenous technology contributing in the better performance during earthquake: A case study of Bhaktapur city. Journal of Science and Engineering 2: 41-45.

Gautam D. 2015a. Monsoon woes: quakes portend aggravation. The Himalayan Times National Daily XIV (234): 8

Gautam, D. 2015b. Indigenous versus modern: building with cultural features. The Himalayan Times National Daily XIV 84: 8.

Gautam D, Rodrigues R. 2015. Architectural and structural characteristics of indigenous Newari Chhen: Study of seismic risk and resilience in the historic urban nucleus of Bhaktapur city, Nepal. Paper presented at the $14^{\text {th }}$ International Symposium on New Technologies for Urban Safety of Mega Cities in Asia (USMCA-2015), October 29-31, Kathmandu, Nepal.

Gautam D, Bhetwal KK, Rodrigues H, Neupane P, Sanada Y. 2015. Observed damage patterns on buildings during 2015 Gorkha (Nepal) earthquake. Paper presented at the $14^{\text {th }}$ International Symposium on New Technologies for Urban Safety of Mega Cities in Asia (USMCA-2015), October 29-31, Kathmandu, Nepal.

GhaffarianHoseini, A., U. Berardi, N.D. Dahlan, and A. GhaffarianHoseini. 2014. What can we learn from Malay vernacular houses? Sustainable Cities and Society 13(2014): 157-170.

Gulkan P, Langebach R. 2004. The earthquake resistance of traditional timber and masonry dwellings in Turkey. Paper presented at the $13^{\text {th }}$ World Conference on Earthquake Engineering, Vancouver, B.C., Canada, paper no. 2297.

IS (Indian Standard). 456-2000. Plain and reinforced concrete-code of practice (fourth revision). Bureau of Indian Standard, New Delhi.
IS (Indian Standard). 1893-2002. Criteria for earthquake resistant design of structures (fifth revision). Bureau of Indian Standard, New DelhilS (Indian Standard) 1893-2002 Criteria for earthquake resistant design of structures (fifth revision). Bureau of Indian Standard, New Delhi

Jiboye AD. 2014. Significance of house type as a determinant of residential quality in Osogbo, Southwest, Nigeria. Frontiers of Architectural Research. http://dx.doi.org/10.1016/j.foar.2013.11.006. Accessed 12 Feb 2015

Jordan, P., and S. O'Neill. 2010. Untangling cultural heritage: language diversity and long-house architecture on Pacific northwest coast. Philosophical Transactions of the Royal Society B 365: 3875-3888. doi:10.1098/rstb.2010.0092.

JSCE (Japanese Society of Civil Engineers). 1989. Reconnaissance report on the 21 August 1988 earthquake in the Nepal-India border region, Report No. B-63-4

Langenbach R. 2010. Rescuing the baby from the bathwater: traditional masonry as earthquake-resistant construction. Paper presented at the $8^{\text {th }}$ International Masonry Conference, Dresden.

Langenbach R. 2015. Vernacular earthquake resistant architecture in Himalaya. Seismic Retrofitting: Learning from Vernacular Architecture - Correia, Lourenço \& Varum (Eds), Taylor and Francis.

Lima A, Gomes F, Carlos GD, Viana D, Correia MR. 2015. Seismic-resistant features in Lower Alentejo's vernacular architecture. Seismic Retrofitting: Learning from Vernacular Architecture - Correia, Lourenço \& Varum (Eds), Taylor and Francis.

Malalgoda, C., D. Amaratunga, and R. Haigh. 2014. Challenges in creating a disaster resilient built environment. Paper presented on the 4th International Conference on Building Resilience, Building Resilience 2014, 8-10 September 2014, Salford Quays, United Kingdom. Procedia Economics and Finance 18(2014): 736-744.

Moles O, Caimi A, Islam MS, Hossain TR, Podder RK. 2014. From local building practices to vulnerability reduction: Building resilience through existing resources, knowledge and know-how. Paper presented on $4^{\text {th }}$ International Conference on Building Resilience 2014, Salford Quays, United Kingdom.

Mundo-Hernandez, J.J., J. Hernandez-Alvarez, C. Valerdi-Nochebuena Ma, J. Sosa-Oliver, and M.A. Rugerio-Quintero. 2013. Housing quality and migration in Mexico. European International Journal of Science and Technology 2(2): 194-202.

NBC (Nepal Building Code). 1994. Ministry of Physical Planning and Works, Government of Nepal (different volumes).

Nguyen, A.T., Q.B. Tran, D.Q. Tran, and S. Reiter. 2011. An investigation on climate responsive design strategies of vernacular housing in Vietnam. Building and Environment 46(2011): 2088-2106. doi:10.1016/j.buildenv.2011.04.019.

NPC (National Planning Commission). 2015. Post Disaster Need Assessment (Vol. A and B). Government of Nepal.

Oktay, D., and K. Pontikis. 2008. In pursuit of humane and sustainable housing patterns on the islands of Cyprus. International Journal of Sustainable Development \& World Ecology 15(2008): 179-188. doi:10.3843/SusDev.15.3:1.

Ortega J, Vasconcelos G, Correia M, Rodrigues H, Lourenco PB, Varum H. 2015. Evaluation of seismic vulnerability assessment parameters for Portuguese vernacular constructions with nonlinear numerical analysis. 5th ECCOMAS Thematic Conference on Computational Methods in Structural Dynamics and Earthquake Engineering, Crete Island, Greece, 25-27 May 2015

Poletti E, Vasconcelos G, Lourenco P. 2015. Timber frames as an earthquake resisting system in Portugal. Seismic Retrofitting: Learning from Vernacular Architecture - Correia, Lourenço \& Varum (Eds), Taylor and Francis.

Rana, B.S.J.B. 1935. The great earthquake of Nepal (Nepalko Mahabhukampa) [in Nepali]. Kathmandu: Jorganesh Press.

Saleh, M.A.E. 2001. The decline vs the rise of architectural and urban forms in the vernacular villages of southwest Saudi Arabia. Building and Environment 36(2001): 89-107

SDMC (SAARC Disaster Management Centre). 2008. Indigenous knowledge for disaster risk reduction in South Asia. New Delhi: SDMC.

Tutuko, P., and Z. Shen. 2014. Vernacular pattern of housing development for home-based enterprises in Malang, Indonesia. International Review of Spatial Planning and Sustainable Development 2(3): 53-67.

UN Habitat Pakistan and National Disaster Management Authority of Pakistan. 2009. Dhajji Construction for one and two storey earthquake resistant houses, a guide book for technicians and artisans.

UNDP (United Nations Development Program). 2008. Koshi (Nepal) Flood Report.

Varum H, Rodrigues H, Lourenco P, Vasconcelos G. 2015. Seismic behaviour of vernacular architecture. Seismic Retrofitting: Learning from Vernacular Architecture - Correia, Lourenço \& Varum (Eds), Taylor and Francis.

Wided, B.R., H. Abdelmadjid, and N. Mohamed. 2012. The future of ksar in sustainable development. Energy Procedia 18(2012): 35-42. doi:10.1016/j. egypro.2012.05.015. 
Widera B, Despang M. 2013. Rediscovering dwelling. Paper presented on

PLEA2013-29 $9^{\text {th }}$ Conference, Sustainable Architecture for a Renewable Future, Munich, Germany 10-12 September 2013.

Winarno S, Griffith A, Stephenson P. 2008. Earthquake risk reduction to nonengineered buildings: a study of practice in Indonesia. Procs $24^{\text {th }}$ Annual ARCOM Conference, ed. Dainty, A., Cardiff, UK, pp. 729-737.

Yamin LE, Phillips CA, Reyes JC, Ruiz DM. 2004. Seismic behavior and rehabilitation alternatives for adobe and rammed earth buildings. Paper presented on 13th World Conference on Earthquake Engineering Conference Proceedings, Vancouver, British Columbia, Canada, August 1-6, 2004. Paper No. 2942. Yin, R.K. 2003. Case study research: Design and methods, 3rd ed. Thousand Oaks: Sage.

Yung, E.H.K., C. Langston, and E.H.W. Chan. 2014. Adaptive reuse of traditional Chinese shop houses in government-led urban renewal projects in Hong-Kong. Cities 39(2014): 87-98.

Zhai, Z., and J.M. Previteli. 2010. Ancient vernacular architecture: characteristics categorization and energy performance evaluation. Energy and Buildings 42(2010): 357-365.

\section{Submit your manuscript to a SpringerOpen ${ }^{\odot}$ journal and benefit from:}

- Convenient online submission

- Rigorous peer review

- Immediate publication on acceptance

- Open access: articles freely available online

- High visibility within the field

- Retaining the copyright to your article

Submit your next manuscript at $\boldsymbol{s p r i n g e r o p e n . c o m ~}$ 